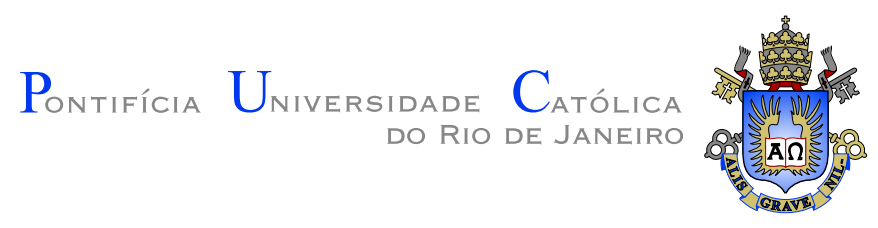

Maíra Athanázio de Cerqueira Gatti

\title{
Engineering Self-Organizing Emergent Multi-Agent Systems: A Design Method and Architecture
}

Thesis presented to the Postgraduate Program in Informatics of the Departamento de Informática PUC-Rio as partial fulfillment of the requirements for the degree of Doutor em Informática

Advisor: Prof. Carlos José Pereira de Lucena 


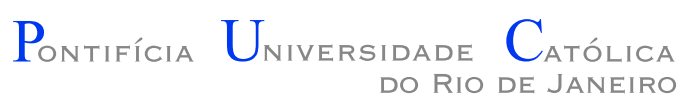

\title{
Maíra Athanázio de Cerqueira Gatti
}

\section{Engineering Self-Organizing Emergent Multi-Agent Systems: A Design Method and Architecture}

Thesis presented to the Postgraduate Program in Informatics of the Departamento de Informática PUC-Rio as partial fulfillment of the requirements for the degree of Doutor em Informática.

\author{
Prof. Carlos José Pereira de Lucena \\ Advisor \\ Departamento de Informática - PUC-Rio
}

Prof. Vera Maria Benjamim Werneck Departamento de Informática e Ciência da Computação UERJ

Prof. Viviane Torres da Silva Departamento de Ciência da Computação - UFF

Prof. Antônio Furtado Departamento de Informática - PUC-Rio

Prof. Bruno Feijó Departamento de Informática - PUC-Rio

Prof. José Eugênio Leal

Coordinator of the Centro Técnico Científico da PUC-Rio

Rio de Janeiro , 21/12/2009 
All rights reserved.

\section{Maíra Athanázio de Cerqueira Gatti}

Maíra Gatti graduate in Informatics and Computer Science from Rio de Janeiro State University (2004) and master's at Informatics in Software Engineering from Pontifícia Universidade Católica do Rio de Janeiro (2006) in cooperation with Laboratoire d'informatique de Paris 6, Université Pierre et Marie Curie (Paris 6) France. During her PhD, she had collaborative period in King's College London, U. of London, grantee of CNPq, Scholarship award. And in The School of Computer Science, University of Waterloo, Canada, grantee of $\mathrm{CNPq}-$ Funding project, Scholarship award. She has experience in Computer Science, focusing on Software Engeneering, acting on the following subjects: multi-agent systems, selforganizing systems, adaptive systems, distributed systems, service-oriented systems, fault-tolerance, autonomic computing and computational biology.

Bibliographic data

Gatti, Maíra Athanázio de Cerqueira

Engineering Self-Organizing Emergent Multi-Agent Systems: A Design Method and Architecture / Maíra Athanázio de Cerqueira Gatti; advisor: Carlos José Pereira de Lucena. - Rio de Janeiro : PUC-Rio, Departamento de Informática, 2009.

v., 153 f: il. ; $29,7 \mathrm{~cm}$

1. Tese (Doutorado em Informática) - Pontifícia Universidade Católica do Rio de Janeiro, Rio de Janeiro, 2009.

Inclui bibliografia.

1. Departamento de Informática - Tese. 2. AutoOrganização. 3. Projeto. 4. Simulação. 5. Arquitetura. 6. Sistemas Multi-Agentes. 7. Engenharia de Software. I. Lucena, Carlos José Pereira de. II. Pontifícia Universidade Católica do Rio de Janeiro. Departamento de Informática. III. Título. 


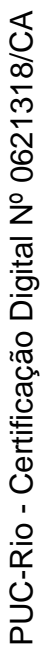

To dad and mom. 


\section{Acknowledgments}

I would like to thanks everyone who helped me during the development of this work, this includes my advisor Prof. Dr. Carlos Lucena, the Software Engineering Lab's research group (LES) from the PUC-Rio university, the LANDIC research group from the UFRJ university and the CNPq - National Counsel of Technological and Scientific Development agency for giving me the financial support during my $\mathrm{PhD}$.

Many thanks goes out to Prof. Dr. Michael Luck for giving me the opportunity to work with the Agents and Intelligent Systems (AIS) sub-group of the Software Engineering research group in the Department of Computer Science at King's College London. The friendly and supportive atmosphere inherent to the AIS group contributed essentially to the final outcome of my studies. I am also grateful to the King's College London for giving me the opportunity to work as a Visiting Research Associate in the Department of Computer Science during my PhD.

Finally, a very special thanks goes out to my love Rodrigo, my parents, my British family, specially Linda, and all my dearest friends. 


\section{Resumo}

Gatti, Maíra Athanázio de Cerqueira; Lucena, Carlos José Pereira de. Engenharia de Sistemas Multi-Agentes AutoOrganizáveis: Um Método de Projeto e Arquitetura. Rio de Janeiro, 2009. 153p. Tese de Doutorado - Departamento de Departamento de Informática, Pontifícia Universidade Católica do Rio de Janeiro.

Arquitetos de software utilizam cada vez mais mecanismos de autoorganização para projetar sistemas distribuídos em um ambiente dinâmico, com ruído e imprevisível. Neste cenário, além de não existir uma entidade centralizadora que possua o conhecimento completo do estado do ambiente como um todo, mecanismos de auto-organização são principalmente inspirados pela natureza e permitem o comportamento com controle descentralizado. Existem duas linhas de pesquisa que direcionam esta tese: a primeira, como é o caso de qualquer paradigma de engenharia de software, o sucesso e abrangência de uso de sistemas auto-organizáveis requerem notações que exploram o uso de abstrações relacionadas a auto-organização e promovam a rastreabilidade a partir de modelos de projeto à código, e requerem métodos de engenharia para prover know-how e guiar um engenheiro durante o projeto da aplicação. A segunda linha de pesquisa foca no incentivo do reuso de software em sistemas auto-organizáveis. Os objetivos desta tese são: prover um método de engenharia baseado em simulação para apoiar o projeto, desenvolvimento, simulação, validação e refinamento de sistemas multi-agentes auto-organizáveis; e prover uma arquitetura baseada em simulação. Um projeto arquitetural ajuda no desenvolvimento de uma estrutura de programa modular e na representação dos relacionamentos de controle entre módulos e encoraja o engenheiro de software a se concentrar no projeto arquitetural antes de se preocupar com otimizações e código. Esta tese apresenta: um ciclo de vida de desenvolvimento iterativo baseado no Processo Unificado, SSOA - uma arquitetura de auto-organização baseada em simulação, e o framework que implementa a arquitetura. O método de projeto e a arquitetura foram avaliados através de três domínios de aplicação diferentes: veículos guiados automatizados, contratos que governam sistemas multi-agentes emergentes, e modelagem computacional do comportamento de células-tronco.

\section{Palavras-chave}

Auto-Organização; Projeto; Simulação; Arquitetura; Sistemas Multi-Agentes; Engenharia de Software; 


\section{Abstract}

Gatti, Maíra Athanázio de Cerqueira; Lucena, Carlos José Pereira de. Engineering Self-Organizing Emergent Multi-Agent Systems: A Design Method and Architecture. Rio de Janeiro, 2009. 153p. DSc Thesis — Departamento de Informática, Pontifícia Universidade Católica do Rio de Janeiro.

Software architects are increasingly relying on self-organizing mechanisms to design distributed systems within a dynamic, noisy and unpredictable environment. At any point in time, no centralized entity has complete knowledge of the state of the environment as a whole and self-organizing mechanisms are mainly naturally-inspired which enables the decentralized control. There are two tracks that drive the research in this thesis: first, as it is the case with any new software engineering paradigm, the successful and widespread deployment of self-organizing systems require notations that explore the use of self-organizing related abstractions and promote the traceability from the design models to code, and engineering methods that provides know-how and guides an engineer during an application design. The second research track is to promote software reuse of self-organizing systems. This thesis's goals are: to provide a simulation-based engineering method to support the design, development, simulation, validation and refinement of self-organizing multi-agent systems; and to provide a simulation-based architecture. An architectural design helps on the development of a modular program structure and on the representation of the control relationships between modules and encourages the software engineer to concentrate on architectural design before worrying about optimizations or code. We present: an iterative development life-cycle based on a customization of the Unified Process, the SSOA - Simulation-based Self-Organizing Architecture -, and the framework that implements the architecture. We have evaluated the design method and architecture using three different application domains: the automated guided vehicles, the contracts that govern emergent multi-agent systems, and the stem cell behavior computational modeling.

\section{Keywords}

Self-Organization; Design; Simulation; Architecture; Multi-Agent Systems; Software Engineering; 


\section{Contents}

1 Introduction $\quad 14$

1.1 Problem Statement $\quad 15$

$\begin{array}{lll}1.2 \text { Goals } & 17\end{array}$

$\begin{array}{lll}1.3 & \text { Contributions } & 18\end{array}$

$\begin{array}{lll}1.4 & \text { Structure of the Thesis } & 19\end{array}$

2 Background $\quad 21$

2.1 Self-Organizing Emergent Systems 21

2.2 ABS: Agent-based Simulation 25

2.3 Case Studies 28

$\begin{array}{lll}2.4 & \text { Chapter Remarks } & 37\end{array}$

3 Notational Support $\quad 38$

3.1 Information Flow Design 38

3.2 UML Customization with Coordinated Statecharts 39

3.3 Exemplar Application: Toward a Self-Organizing Pattern Language 45

3.4 Chapter Remarks $\quad 57$

4 SSOA: A Simulation-based Self-Organizing Architecture $\quad 58$

$\begin{array}{lll}4.1 & \text { SSOA Iterative Life-Cycle } & 58\end{array}$

4.2 The Architecture Requirements 63

4.3 The SSOA Description and Dynamics 68

4.4 A Framework that Implements SSOA $\quad 75$

4.5 Implementation Blueprints $\quad 76$

$\begin{array}{ll}4.6 & \text { Chapter Remarks } \\ \end{array}$

5 Case Studies $\quad \mathbf{7 9}$

5.1 The Automated Guided Vehicles 79

5.2 Contracts that Govern Emergent Multi-Agent Systems 87

5.3 Computational Modeling of Stem Cell Behavior 100

5.4 Manager Overhead 111

5.5 Chapter Remarks 111

6 Related Work 112

6.1 Modeling and Designing Self-Organizing Systems 112

6.2 Architectures and Middlewares for Self-Organizing Systems 121

6.3 Validation and Verification of Self-Organizing Systems 123

$\begin{array}{lll}6.4 & \text { Chapter Remarks } & 125\end{array}$

$7 \quad$ Conclusions and Future Work $\quad 127$

$\begin{array}{lll}7.1 & \text { Contributions } & 127\end{array}$

$\begin{array}{llr}7.2 & \text { Limitations } & 129\end{array}$

$\begin{array}{lll}7.3 & \text { Future Directions } & 130\end{array}$

A List of Publications (PhD related) 151 
A.1 Article in Journal/Book

A.2 Contributions at International Conferences, Published in the Proceedings

A.3 Contributions at National (Brazilian) Conferences, Published in the Proceedings

152

A.4 Technical Reports (selected) 


\section{List of Figures}

2.1 AGV case: example factory lay-out, from [De Wolf 2007] 29

2.2 The Aerospace Scenario 31

2.3 The Stem Cell Division and Differentiation Process 35

3.1 Cordinated Statecharts Concept 41

3.2 The customized UML 2.0 meta-model 42

3.3 The coordinated state machine notation for an agent's behavior 42

3.4 Coordinated state machine notation - input versus output coordinated signal perceptions 44

3.5 Self-Organizing Design Patterns and Their Relationships 47

3.6 Micro-Architecture Structure 48

3.7 Micro-Architecture Dynamics $\quad 49$

3.8 AGV Structure $\quad 51$

3.9 AGV Dynamics: Dispatching Property 52

4.1 The Design Iterative Life-Cycle w.r.t the Unified Process 59

4.2 Coordination Support for Feedback Loops 65

4.3 The Multi-Environment Perspective 66

4.4 The Multi-Environment Perspective: a)Graph: each agent or sub-environment can be located in a node and perceives its neighbors; b) 2D double point grid: each agent or subenvironment can be located in a discrete $2 \mathrm{D}$ double point position in the grid; c)3D continuous grid: each agent or subenvironment can be located in a 3D floating point grid. $\quad 67$

4.5 The SSOA Components 68

4.6 The MESOF Meta-Model 69

$\begin{array}{lll}4.7 & \text { The coordination between two agents } & 72\end{array}$

$\begin{array}{ll}4.8 & \text { The Manager Meta-Model } \\ & 74\end{array}$

5.1 The AGV Class Diagram (partial view) 81

5.2 The Dispatching Property w.r.t feedback loop 82

5.3 AGV Goals and SSOA Manager Component instantiation 84

5.4 Routing throughput analysis $\quad 86$

$\begin{array}{lll}\text { 5.5 Dispatching throughput analysis } & 87\end{array}$

5.6 The Aerospace Aftercare System Class Diagram (partial view) 88

5.7 The Aircraft and Airline Operator Coordinated Statecharts 93

5.8 The Engine Manufacturer and Part Supplier Coordinated Statecharts 94

5.9 Integration process for maximizing the number of times the aircraft was in the flying state $(N F)$ and minimizing the costs $\begin{array}{ll}\text { regarding norms violations }(N C) & 97\end{array}$

5.10 Plot of metric as specified in $\max A \quad 99$

5.11 The Stem Cell Class Diagram (partial view) 101

5.12 The Spatial Self-Organization 102

5.13 The proteins diffusion and cell perception 103 
5.14 Conceptual cell life-cycle behavior $\quad 106$

5.15 Gap 1 phase checkpoint coordinated statecharts $\quad 107$

5.16 The desired number of stem cells evolution 110

5.17 Manager overhead in the simulation 111

6.1 The Customised Unified Process from [De Wolf 2007] 114

6.2 Information flows, from [De Wolf 2007] 115

6.3 Architectural pattern featuring environmental agents as artefact administrators, from [Gardelli 2008] 116

6.4 The ADELFE methodology [Picard 2004] 117

7.1 The dynamic meta-model editor 132 


\section{List of Tables}

5.1 Norm structures for contractual clauses in simulation. Nx O refers to an obligation for norm class $\mathrm{x}, \mathrm{Nx} \mathrm{P}$ for a permission $\begin{array}{ll}\text { for norm class } \mathrm{x} & 89\end{array}$

5.2 External Actions $\quad 91$

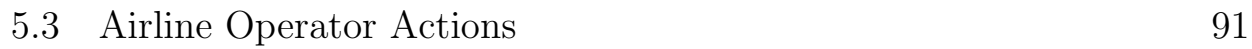

$\begin{array}{ll}5.4 \text { Engine Manufacturer Actions } & 91\end{array}$

5.5 Part Supplier Actions $\quad 92$

5.6 Contracts Variations 98

5.7 External Actions 104

5.8 Protein and Intracellular Actions $\quad 105$

5.9 Cell life-cycle Actions. 105 
Reuse: Is someone using your novel design to solve similar problems?

Maíra Gatti. 